\title{
Influence of Irrigation Regimes, Row Spacing and Varieties on Biomass Partitioning in Summer Mungbean (Vigna radiata (L)) under Middle Gujarat Agro-Climatic Zone
}

\author{
B. I. Karande*, H. R. Patel, D. D. Patil, S. B. Yadav and M. M. Lunagaria \\ Department of Agricultural Meteorology, B. A. College of Agriculture, Anand Agricultural \\ University, Anand - 388 001, Gujarat, India \\ *Corresponding author
}

Keywords

Mungbean (Vigna radiata $(\mathrm{L})$.

Wilczek), Row

Spacing, Varieties, Agro-Climatic Zone

Article Info

Accepted:

25 July 2019

Available Online:

10 August 2019

\section{A B S T R A C T}

Field experiment was conducted at B. A. College of Agriculture, Anand Agricultural University, Anand during summer season for two consecutive years 2015 and 2016 to study the influence of irrigation regimes $\left(\mathrm{I}_{1}: 0.8\right.$ IW: CPE ratio, $\mathrm{I}_{2}$ : $0.6 \mathrm{IW}$ : CPE ratio and $\mathrm{I}_{3}: 0.4 \mathrm{IW}$ : CPE ratio) and row spacing $\left(\mathrm{S}_{1}: 45 \mathrm{~cm}\right.$ and $\left.\mathrm{S}_{2}: 30 \mathrm{~cm}\right)$ on biomass partition of two varieties $\left(\mathrm{V}_{1}\right.$ : Meha and $\mathrm{V}_{2}$ : GM-4). Results revealed that periodical leaf weight, stem weight were recorded highest at all 10 days interval with irrigation scheduling at $0.8 \mathrm{IW}$ : $\mathrm{CPE}\left(\mathrm{I}_{1}\right)$ ratio while lowest was recorded at $0.4 \mathrm{IW}$ : $\mathrm{CPE}\left(\mathrm{I}_{1}\right)$ ratio. Variety Meha $\left(\mathrm{V}_{1}\right)$ produced higher biomass as compared to GM-4 $\left(\mathrm{V}_{2}\right)$ from 50 DAS till harvest of crop resulted in higher biomass accumulation and final yield. Row spacing $30 \mathrm{~cm}\left(\mathrm{~S}_{2}\right)$ produced higher biomass viz., leaf dry weight, stem dry weight and root dry than $45 \mathrm{~cm}\left(\mathrm{~S}_{1}\right)$ during both the year. Highest root weight was recorded with irrigation scheduling at $0.4 \mathrm{IW}$ : $\mathrm{CPE}\left(\mathrm{I}_{3}\right)$ ratio while lowest recorded under treatment 0.8 IW: $\mathrm{CPE}\left(\mathrm{I}_{1}\right)$.

\section{Introduction}

Pulses are an important food crop worldwide, especially in India where they are a major source of vegetable proteins and micronutrients including iron for poorer sections of the population (Nair et al., 2013). In India, the demand for pulses is increasing, but since the early 1960s crop area and production have not increased (FAO, 2016). Mungbean (Vigna radiata (L). Wilczek) is a pulse crop that is particularly attractive for farmers in India because of its short duration and decent performance under adverse climatic conditions such as heat, drought and salinity (Hanumantha Rao et al., 2016). It is the third important pulse crop after chickpea and pigeon pea, cultivated throughout India 
for its multipurpose uses as vegetable, pulse, fodder and green manure crop. It is a good source of protein (20-24 \%), carbohydrates (60-62 \%), water $(10 \%)$, fat $(1.0 \%)$, fiber $(4.0 \%)$ and ash $(3.0 \%)$. Green gram protein is deficient in methionine and cysteine but rich in lysine making it an excellent compliment to rice in terms of balanced human nutrition (Yadav et al., 2009). It is a good source of the mineral, pro-vitamin A, B complex and ascorbic acid. Besides being a rich source of protein, it maintains soil fertility through biological nitrogen fixation in soil and thus plays a vital role in furthering sustainable agriculture (Kannaiyan, 1999).

Irrigation plays a vital role in maintaining high yield level and stability of the crop production. The high yielding varieties of mungbean have been developed but the yield potential of new varieties is not being achieved. As a result, the yield of mungbean is low mainly due to lack of proper agronomic practices. The mungbean crop is very sensitive to irrigation and radiation interception. The poor or profuse vegetative growth both cause poor yields. Good water management provides many benefits including higher yields, better-quality crops, conservation of water and efficient uptake of nutrients. The goal of irrigation scheduling is to apply the proper amount of water at the proper time to meet crop needs without flushing soil moisture and nutrients below the rooting zone. One of the reasons of low yield of mungbean is inappropriate plant population. Farmers usually grow mungbean by broadcasting method of sowing which requires higher seed rate and tended to maintain inconsistent plant stand establishment, poor growth and difficulty in managing pests and diseases as well as intercultural operations. Plant population should be kept optimum to obtain maximum yield. Although spacing of $30 \mathrm{~cm}$ and $10 \mathrm{~cm}$ between rows and plants respectively have been recommended by the national programme on pulses for mungbean crop. There is a need to use an appropriate seed rate and row spacing to harvest maximum yield of mungbean.

\section{Materials and Methods}

The experiment was laid out at Agronomy Farm, B. A. College of Agriculture, Anand Agricultural University, Anand, Gujarat during summer seasons of 2015 and 2016 in split plot design with irrigation levels as main plot $\left(\mathrm{I}_{1}-0.8 \mathrm{IW}\right.$ : CPE, $\mathrm{I}_{2}-0.6 \mathrm{IW}$ : $\mathrm{CPE}$ and $\mathrm{I}_{3}-$ $0.4 \mathrm{IW}$ : CPE), row spacing $\left(\mathrm{S}_{1}: 45 \mathrm{~cm}\right.$ and $\mathrm{S}_{2}$ : $30 \mathrm{~cm})$ and variety $\left(\mathrm{V}_{1}\right.$ : Meha and $\mathrm{V}_{2}$ : GM 4) as sub plot treatments. The soil type of the experimental site is sandy loam a true representative soil of the region. Recommended agronomic practices were followed to raise the crop. The cumulative pan evaporation values were calculated from daily pan evaporation measured with the help of USWB class 'A' open pan evaporimeter installed at meteorological observatory, which was in the proximity of the experimental plot. The $50 \mathrm{~mm}$ of irrigation water applied in surface flooding was measured by $7.5 \mathrm{~cm}$ head Parshall flume. Biomass observations for leaf dry weight, stem dry weight and root dry weight were taken from five selected plants from each plot at 10 days interval started 20 days after sowing.

\section{Results and Discussion}

Periodical observations of mungbean recorded at 10 days interval started from 20 days after sowing till harvest as influenced by irrigation scheduling, varieties and row spacing.

\section{Leaf weight $\left(\mathrm{g} \mathrm{m}^{-2}\right)$}

\section{Effect of irrigation levels}

Results reveals that higher dry weight $(110.8 \mathrm{~g}$ $\mathrm{m}^{-2}, 158.4 \mathrm{~g} \mathrm{~m}^{-2}, 179.4 \mathrm{~g} \mathrm{~m}^{-2}$ and $190.9 \mathrm{~g} \mathrm{~m}^{-2}$ ) 
was recorded in the treatment of irrigation level $\mathrm{I}_{1}$ (0.8 IW: CPE ratio) at 60, 70 DAS and at harvest, respectively [Fig. 1 (a)]. While, the lowest leaf dry weight was recorded at all intervals i.e. at 20,30, 40, 50 and 60 DAS and at harvest in the irrigation treatment level $\mathrm{I}_{3}$ (0.4 IW: CPE ratio) during year 2015 .

Similar trends were observed during the year 2016 among the different irrigation treatments at 20,30, 40, 50 and 60 DAS and at harvest [Fig. 1 (a)]. Increase in plant growth in terms of leaf dry weight $\left(\mathrm{g} \mathrm{m}^{-2}\right)$ might be due to increase in the total amount of water applied and soil moisture maintained in readily available ranges might have provided condition for favourable growth in terms of cell division and increase in cell size resulting in expansion of plant height. The present findings are close agreement with those reported by Dabhi et al., (2000), Kavitha and Wahab (2001) and Idnani and Gautam (2008).

\section{Effect of varieties}

Higher leaf dry weight $\left(4.1 \mathrm{~g} \mathrm{~m}^{-2}, 18.9 \mathrm{~g} \mathrm{~m}^{-2}\right.$ and $72.8 \mathrm{~g} \mathrm{~m}^{-2}$ ) was recorded in the variety $\mathrm{V}_{2}$ (GM-4) at 20, 30 and 40 DAS, respectively then $\mathrm{V}_{1}$ (Meha). Higher leaf dry weight $85.2 \mathrm{~g}$ $\mathrm{m}^{-2}, 137.4 \mathrm{~g} \mathrm{~m}^{-2}, 173.4 \mathrm{~g} \mathrm{~m}^{-2}$ and $187.4 \mathrm{~g} \mathrm{~m}^{-2}$ was recorded in the variety $\mathrm{V}_{1}$ (Meha) at 50, 60,70 DAS and at harvest, respectively then $\mathrm{V}_{2}$ (GM-4) during year 2015 [Fig. 1 (b)].

During the year 2016 treatment $\mathrm{V}_{2}$ (GM-4) recorded higher leaf dry weight $9.2 \mathrm{~g} \mathrm{~m}^{-2}, 37.1$ $\mathrm{g} \mathrm{m}^{-2}$ and $63.5 \mathrm{~g} \mathrm{~m}^{-2}$ at 20,30 and 40 DAS. Higher leaf dry weight 113.8, 149.0, 163 and 165 was recorded in the variety $\mathrm{V}_{1}$ (Meha) at $50,60,70$ and at harvest, respectively then $\mathrm{V}_{2}$ (GM-4) during year 2016 [Fig. 1 (b)]. This indicated that GM-4 had initially faster growth and short duration while, Meha showed initial slow growth up to 40 DAS and thereafter gained faster growth with longer duration then GM-4.

\section{Effect of row spacing}

Higher leaf dry weight $\left(10.4 \mathrm{~g} \mathrm{~m}^{-2}, 39.9 \mathrm{~g} \mathrm{~m}^{-2}\right.$, $79.5 \mathrm{~g} \mathrm{~m}^{-2}, 142.0 \mathrm{~g} \mathrm{~m}^{-2}, 158.0 \mathrm{~g} \mathrm{~m}^{-2}, 163.2 \mathrm{~g}$ $\mathrm{m}^{-2}$ and $167.1 \mathrm{~g} \mathrm{~m}^{-2}$ ) was recorded in the narrow row spacing $\mathrm{S}_{2}(30 \mathrm{~cm})$ at $20,30,40$, 50, 60,70 DAS and at harvest, respectively then wider row spacing $S_{1}(45 \mathrm{~cm})$ during year 2015 [Fig. 1 (c)]. Similar trend was observed during year 2016 [Fig. 1 (c)].

This might be due to narrower row spacing increased higher plant population per unit area by which it produced more leaf area per $\mathrm{m}^{-2}$ resulted in higher leaf dry weight $\mathrm{m}^{-2}$. Similar results were reported by Rajput et al., (1993), Sekhon et al., (2002), Jahan and Hamid (2004) and Rasul et al., (2012).

\section{Stem weight $\left(\mathrm{g} \mathrm{m}^{-2}\right)$}

\section{Effect of irrigation levels}

Higher stem dry weight $\left(103.5 \mathrm{~g} \mathrm{~m}^{-2}, 145.7 \mathrm{~g}\right.$ $\mathrm{m}^{-2}, 183.8 \mathrm{~g} \mathrm{~m}^{-2}$ and $187.0 \mathrm{~g} \mathrm{~m}^{-2}$ ) was recorded in the treatment of irrigation level $\mathrm{I}_{1}$ (0.8 IW: CPE ratio) at 50, 60, 70 DAS and at harvest, respectively. While, the lowest stem weight were recorded at all intervals i.e. at 20, 30, 40, 50, 60, 70 DAS and at harvest in the irrigation treatment level $\mathrm{I}_{3}(0.4 \mathrm{IW}$ : CPE ratio) during year 2015 [Fig. 2 (a)].

Similar trends were observed during the year 2016 among the different irrigation treatments at 20, 30, 40, 50, 60, 70 DAS and at harvest [Fig. 2 (a)]. Increase in stem weight [Fig. 2 (a)] in irrigation treatment $I_{1}$ might be due to more frequent irrigations were applied as compared to $\mathrm{I}_{2}$ and $\mathrm{I}_{3}$ treatments resulted in optimum soil moisture conditions in soil produced higher stem weight.

Similar findings were reported by Dabhi et al., (2000), Kavitha and Wahab (2001), Idnani and Gautam (2008) and Patel et al., (2016). 
2015
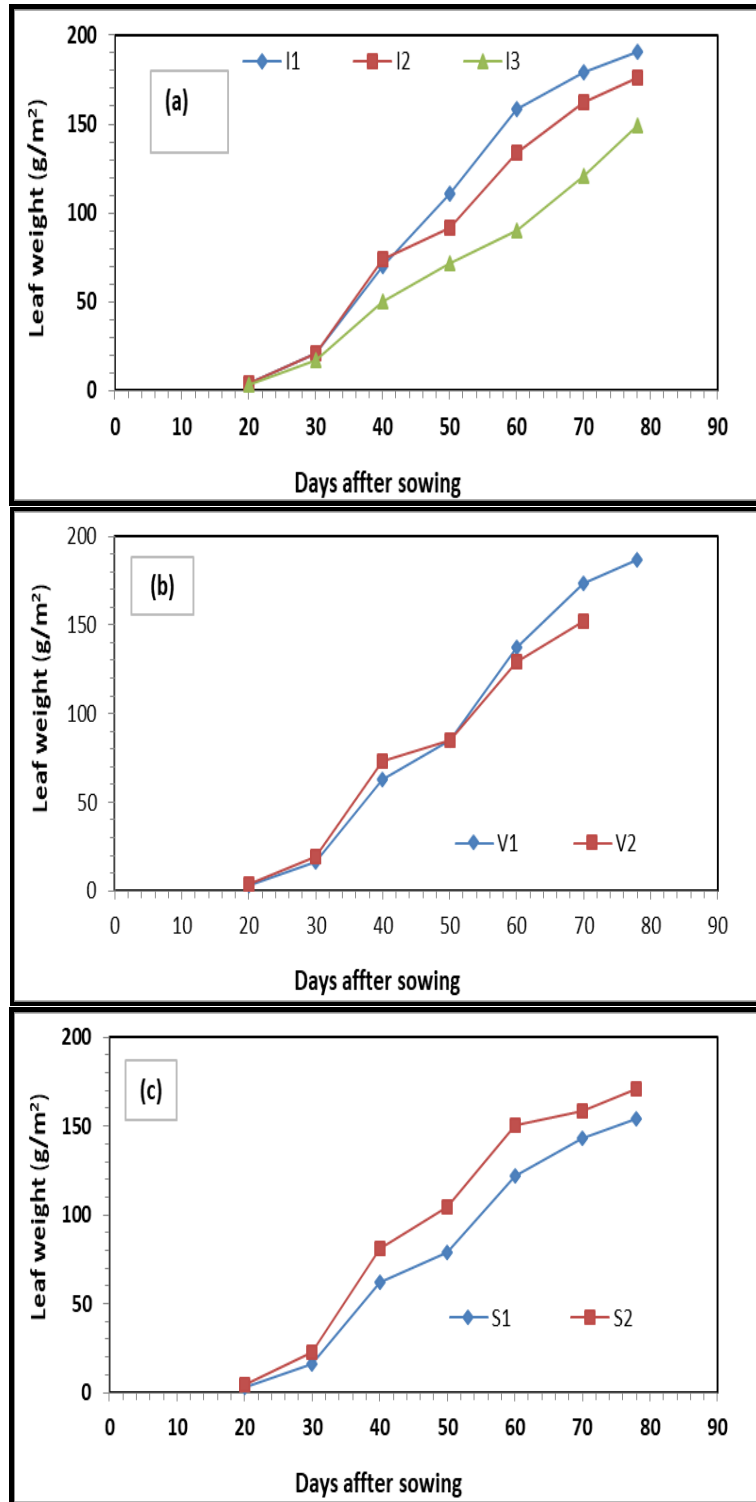

2016
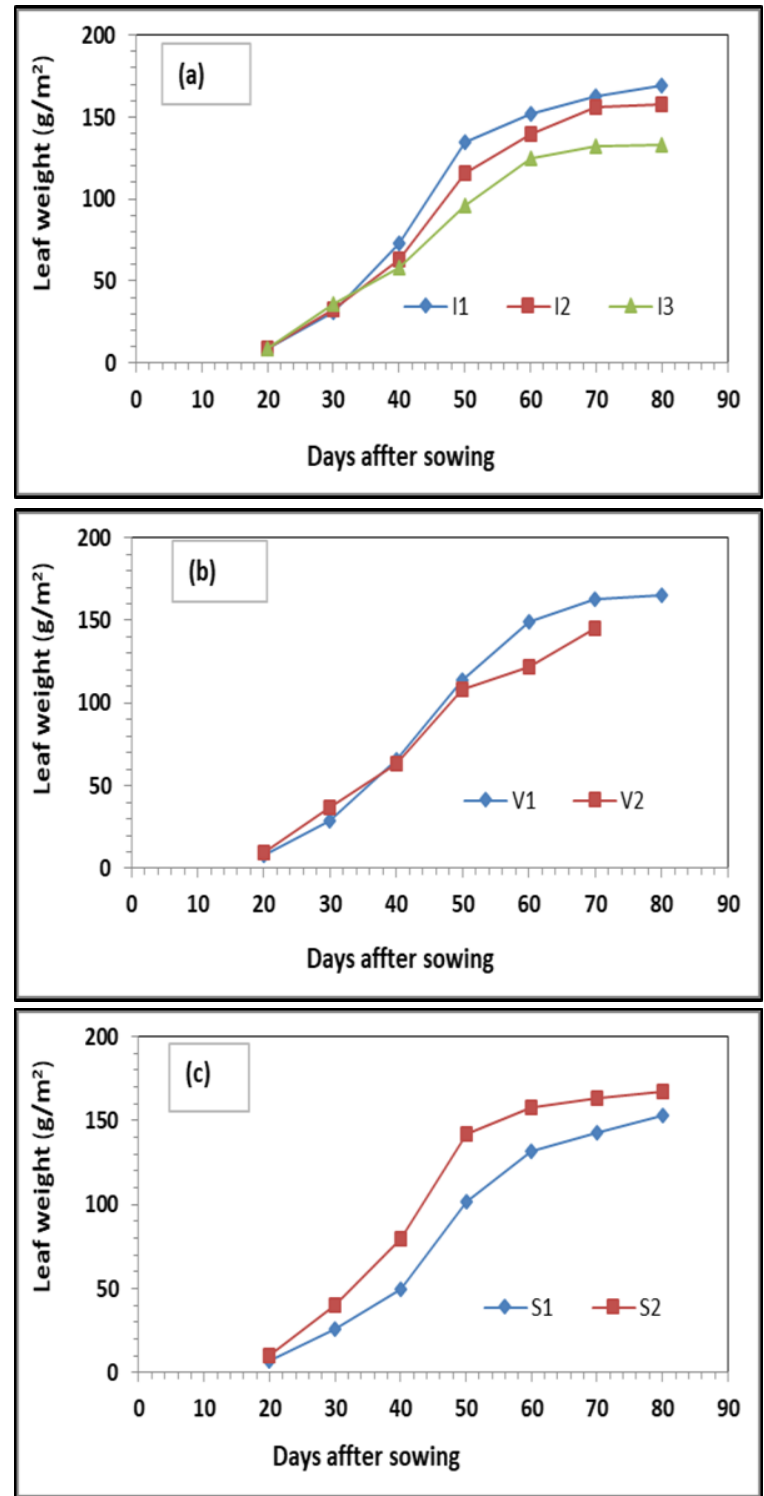

Fig.1 Periodic leaf weight $\left(\mathrm{g} \mathrm{m}^{-2}\right)$ variation in different treatments (a) IW:CPE ratio, (b) varieties and (c) row spacing during 2015 and 2016

2015

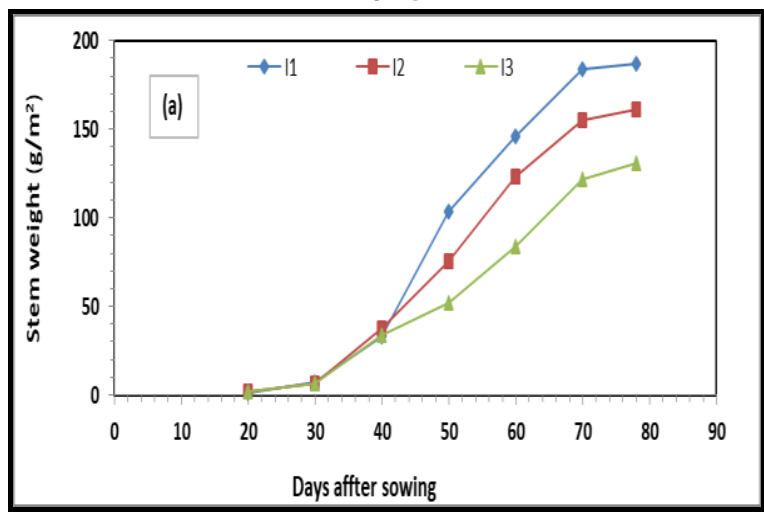

2016

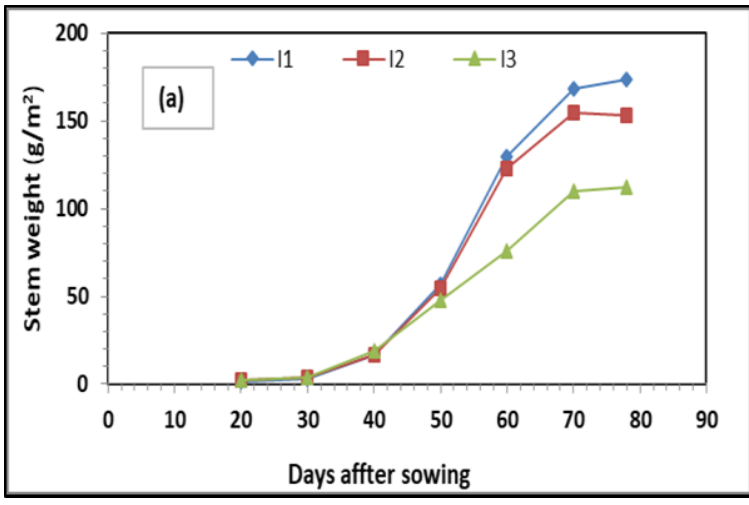



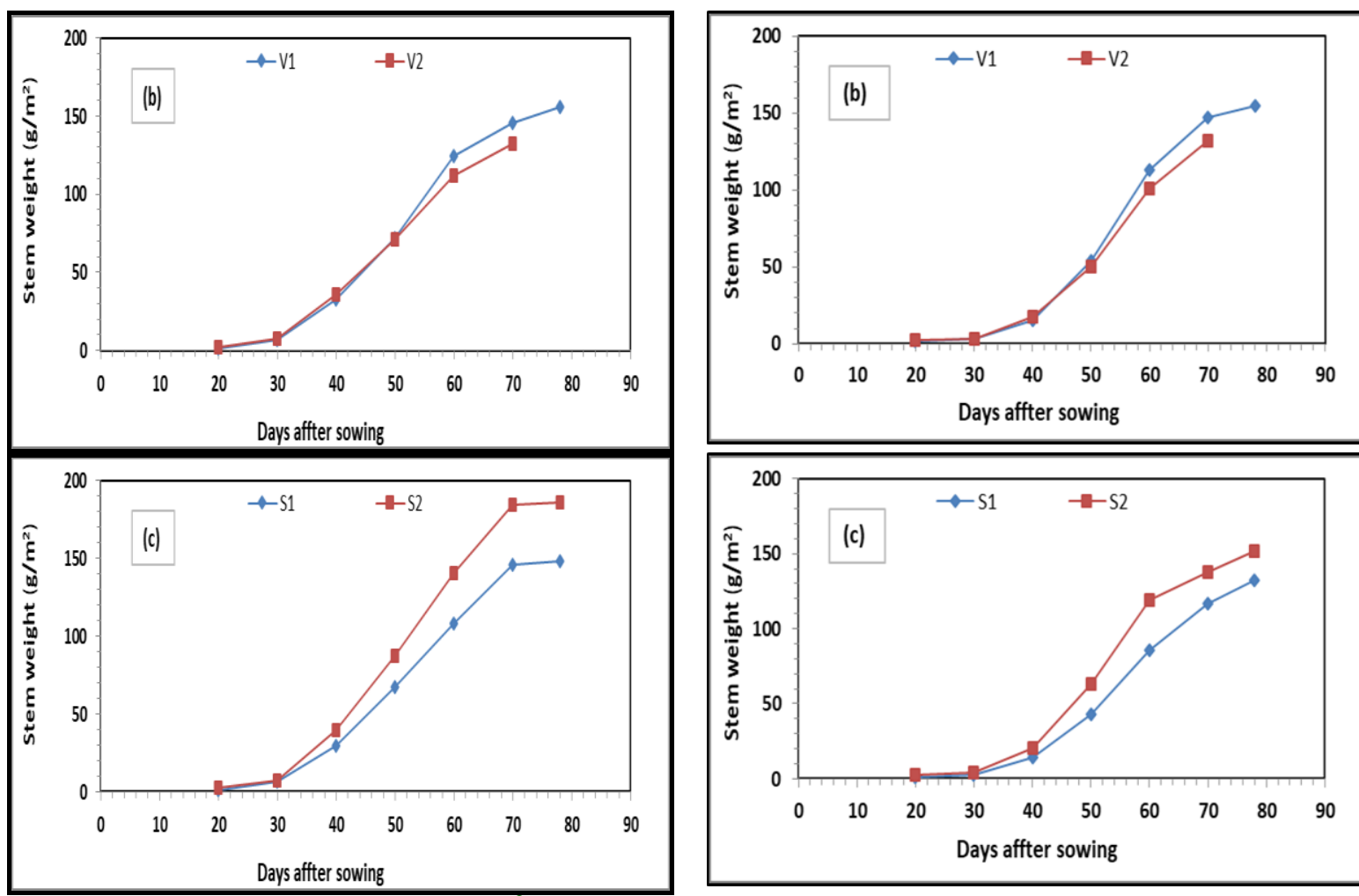

Fig.2 Periodic stem weight $\left(\mathrm{gm}^{-2}\right)$ variation in different treatments (a) IW:CPE ratio, (b) Varieties and (c) row spacing during 2015 and 2016

\section{5}

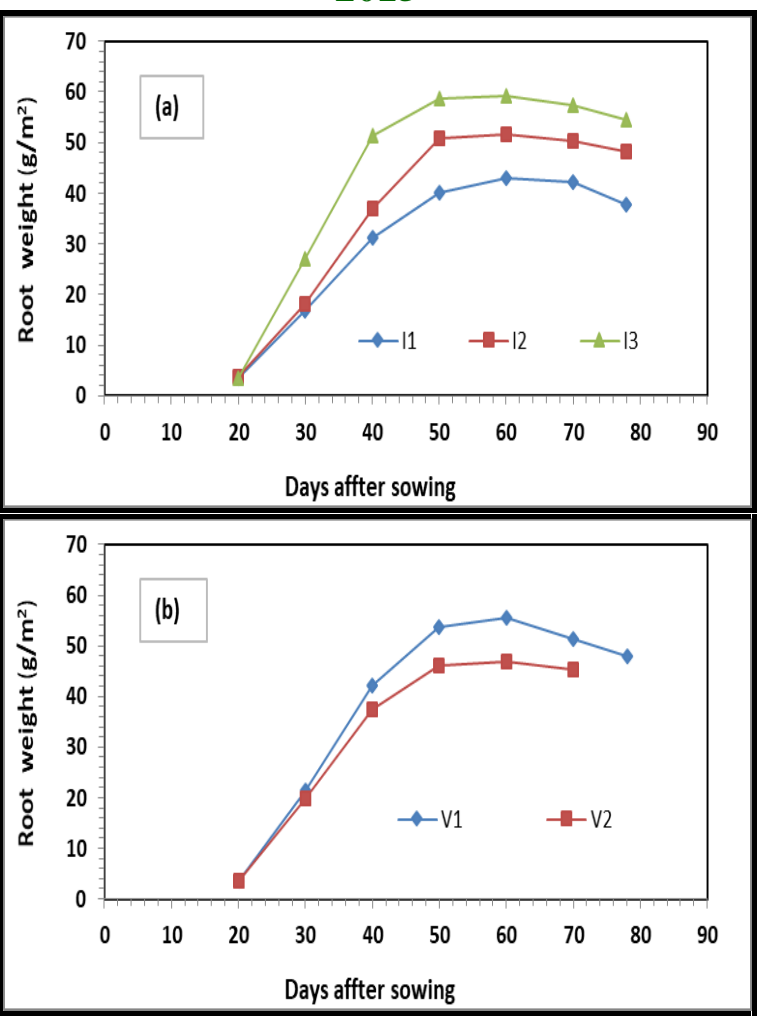

2016
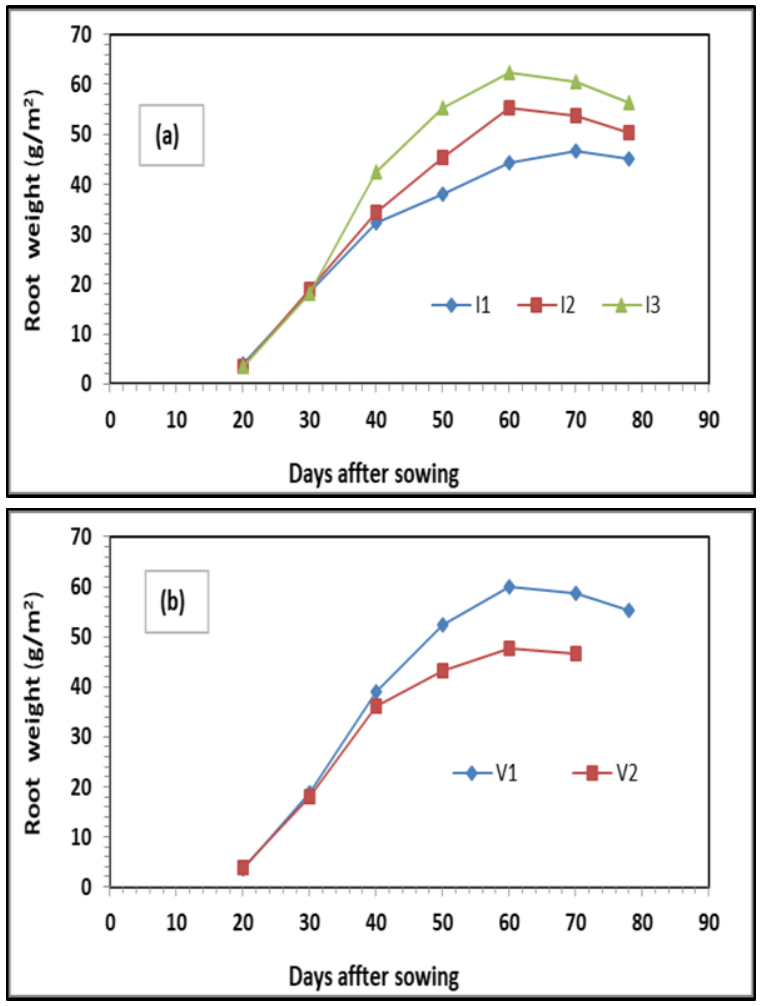

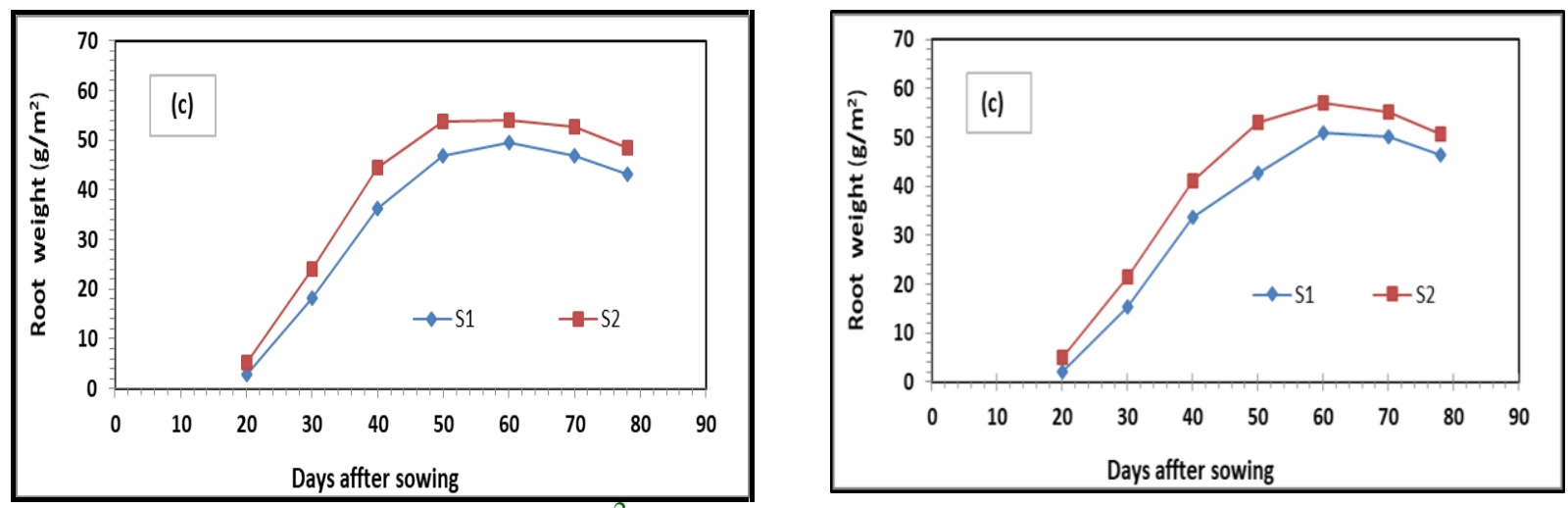

Fig.3 Periodic root weight $\left(\mathrm{g} \mathrm{m}^{-2}\right)$ variation in different treatments (a) IW:CPE ratio, (b) Varieties and (c) row spacing during 2015

\section{Effect of varieties}

Higher stem dry weight $2.2 \mathrm{~g} \mathrm{~m}^{-2}, 7.1 \mathrm{~g} \mathrm{~m}^{-2}$, and $35.5 \mathrm{~g} \mathrm{~m}^{-2}$ was recorded in the variety $\mathrm{V}_{2}$ (GM-4) at 20, 30 and 40 DAS, respectively then $\mathrm{V}_{1}$ (Meha). Higher stem dry weight 72.1 $\mathrm{g} \mathrm{m}^{-2}, 124.6 \mathrm{~g} \mathrm{~m}^{-2}, 145.9 \mathrm{~g} \mathrm{~m}^{-2}$ and $155.9 \mathrm{~g} \mathrm{~m}^{-}$ ${ }^{2}$ was recorded in the variety $\mathrm{V}_{1}$ (Meha) at 50, 60,70 and at harvest, respectively then $\mathrm{V}_{2}$ (GM-4) during year 2015 [Fig. 2 (b)]. During the year 2016 between two varieties, treatment $\mathrm{V}_{2}$ (GM-4) recorded higher stem dry weight $2.2 \mathrm{~g} \mathrm{~m}^{-2}, 3.5 \mathrm{~g} \mathrm{~m}^{-2}$ and $17.6 \mathrm{~g} \mathrm{~m}^{-2}$ was recorded in the variety $\mathrm{V}_{2}(\mathrm{GM}-4)$ at 20 , 30 and 40 DAS, respectively then $\mathrm{V}_{1}$ (Meha). Higher stem dry weight $53.7 \mathrm{~g} \mathrm{~m}^{-2}, 113.3 \mathrm{~g} \mathrm{~m}^{-}$ $2,147.3 \mathrm{~g} \mathrm{~m}^{-2}$ and $154.9 \mathrm{~g} \mathrm{~m}^{-2}$ was recorded in the variety $\mathrm{V}_{1}$ (Meha) at 50, 60, 70 and at harvest, respectively then $\mathrm{V}_{2}(\mathrm{GM}-4)$ during year 2016 [Fig. 2 (b)].

\section{Effect of row spacing}

Higher stem dry weight $\left(2.4 \mathrm{~g} \mathrm{~m}^{-2}, 7.1 \mathrm{~g} \mathrm{~m}^{-2}\right.$, $39.5 \mathrm{~g} \mathrm{~m}^{-2}, 86.9 \mathrm{~g} \mathrm{~m}^{-2}, 140.5 \mathrm{~g} \mathrm{~m}^{-2}, 184.6 \mathrm{~g} \mathrm{~m}^{-}$ 2 and $186.0 \mathrm{gm}^{-2}$ ) was recorded in the narrow row spacing $\mathrm{S}_{2}(30 \mathrm{~cm})$ at $20,30,40,50$, 60,70 DAS and at harvest, respectively then wider row spacing $S_{1}(45 \mathrm{~cm})$ during year 2015 [Fig. 2 (c)]. Similar trend was observed during year 2016 [Fig. 2 (c)]. Similar results were reported by Sekhon et al., (2002), Jahan and Hamid (2004) and Rasul et al., (2012).

\section{Root weight $\left(\mathrm{g} \mathrm{m}^{-2}\right)$}

\section{Effect of irrigation levels}

Higher root weight $(3.4 \mathrm{~g} \mathrm{~m}-2,27.1 \mathrm{~g} \mathrm{~m}-2$, $51.2 \mathrm{~g} \mathrm{~m}-2,58.7 \mathrm{~g} \mathrm{~m}-2,59.1 \mathrm{~g} \mathrm{~m}-2,57.5 \mathrm{~g} \mathrm{~m}-$ 2 and $54.5 \mathrm{~g} \mathrm{~m}-2$ ) was recorded in the irrigation treatment level I3 (0.4 IW: CPE ratio) at 20,30, 40, 50, 60, 70 DAS and at harvest, respectively. While, the lowest root weights were recorded at all intervals i.e. at 20, 30, 40, 50, 60, 70 DAS and at harvest in the irrigation treatment level I1 (0.8 IW: CPE ratio) during the year 2015 [Fig. 3 (a)].

Similar trends were observed during the year 2016 among the different irrigation treatments at 20,30, 40, 50, 60, 70 DAS and at harvest [Fig. 3 (a)]. Higher root dry weight (g m-2) in irrigation treatment I3 might be due to soil moisture stress experienced throughout life period, resulting in more dry matter produced diverted to root growth to extract soil moisture from deeper layers. Under stress conditions plant partitioned more photosynthates to root growth and less to above ground biomass to reduce transpiration losses and extract moisture from deeper layers to meet transpiration demand. Muhammad et al., (1994) reported similar results that under stress condition mungbean divert more biomass partition to root compared to nonstressed conditions. 


\section{Effect of varieties}

Higher root dry weight $\left(42.1 \mathrm{~g} \mathrm{~m}^{-2}, 53.7 \mathrm{~g} \mathrm{~m}^{-}\right.$ , $, 55.6 \mathrm{~g} \mathrm{~m}^{-2}, 51.4 \mathrm{~g} \mathrm{~m}^{-2}$ and $48.0 \mathrm{~g} \mathrm{~m}^{-2}$ ) was recorded in the variety $\mathrm{V}_{1}$ (Meha) at 40, 50, 60, 70 DAS and at harvest respectively, then $\mathrm{V}_{2}$ (GM-4) during year 2015 [Fig. 3 (b)]. Similar trend was observed for root dry weight at all intervals during year 2016 [Fig. 3 (b)]. Othmani et al., (2015) reported similar results for wheat crop for significant varietal differences in root dry weight partitioning

\section{Effect of row spacing}

Higher root dry weight $\left(5.3 \mathrm{~g} \mathrm{~m}^{-2}, 24.1 \mathrm{~g} \mathrm{~m}^{-2}\right.$, $44.3 \mathrm{~g} \mathrm{~m}^{-2}, 53.7 \mathrm{~g} \mathrm{~m}^{-2}, 54.0 \mathrm{~g} \mathrm{~m}^{-2}, 52.6 \mathrm{~g} \mathrm{~m}^{-2}$ and $48.5 \mathrm{~g} \mathrm{~m}^{-2}$ ) was recorded in the narrow row spacing $S_{2}(30 \mathrm{~cm})$ at 20, 30, 40, 50, 60, 70 DAS and at harvest, respectively then wider row spacing $S_{1}(45 \mathrm{~cm})$ during both the years 2015 [Fig. 3(c)] and 2016 [Fig. 3 (c)].

Irrigation at $0.8 \mathrm{IW}: \mathrm{CPE}\left(\mathrm{I}_{1}\right)$ ratio recorded higher leaf dry weight and stem dry weight over irrigation applied at $0.6 \mathrm{IW}$ : $\mathrm{CPE}\left(\mathrm{I}_{2}\right)$ and 0.4 IW: $\mathrm{CPE}\left(\mathrm{I}_{3}\right)$, while highest root weight was recorded under irrigation at $0.4 \mathrm{IW}$ : CPE $\left(\mathrm{I}_{3}\right)$. Variety Meha $\left(\mathrm{V}_{1}\right)$ produced higher leaf dry weight, stem dry weight and root dry weight resulted in higher biomass accumulation and final yield. Row spacing 30 $\mathrm{cm}\left(\mathrm{S}_{2}\right)$ produced higher leaf dry weight, stem dry weight and root dry weight than $45 \mathrm{~cm}$ $\left(\mathrm{S}_{1}\right)$ during both the year.

\section{References}

Dabhi, B. M., Solanki, R. M. and Patel, J. C. (2000). Response of summer green gram to irrigation systems based on IW/CPE ratio. Gujarat Agricultural University Research Journal, 25 (2):2023.

FAO. (2016). FAOSTAT Database on production. Rome. FAO Statistics
Division, Food and Agriculture Organization of the United Nations. Retrieved December 9, 2016, from http://faostat.fao.org/site/ 339/default.aspx

Guriqbal, S., Sekhon, H. S., Gurdip, S., Brar, J. S., Bains, T. S. and Shanmugasundaram, S. (2011). Effect of Plant Density on the Growth and Yield of Mungbean [Vigna radiata (L.) Wilczek] Genotypes under Different Environments in India and Taiwan. International Journal of Agricultural Research, 6: 573-583.

HanumanthaRao, B., Nair, R. M.and Nayyar, H. (2016). Salinity and high temperature tolerance in mungbean [Vigna radiata (L.) Wilczek] from a physiological perspective. Frontiers in Plant Science, 7, 957. doi:10.3389/fpls.2016.00957

Idnani, L. K. and Gautam, H. K. (2008). Water economization in summer greengram (Vigna radiata) as influenced by irrigation regimes and land configurations. Indian J. Agric. Sci., 78(3): 214-219.

Insanullah, F. H. Taj, H. Akbar, A. Basir and Ullah, N. (2002). Effect of row spacing on agronomic traits and yield of mungbean (Vigna radiata $\mathrm{L}$. Wilczek). Asian J. Plant Sci., 1: 328-329.

Jahan, M. S. and Hamid, A. (2004). Effect of population density and planting configuration on dry matter allocation and yield in mungbean (Vigna radiate L.). Pak. J. Biol. Sci., 7: 1493-1498.

Kannaiyan S. Bioresource technology for sustainable agriculture. Associated Publishing Company. New Delhi, 1999, 422

Kavitha, R., and Wahab, K. (2001). Effect of irrigation and mulching practices on growth parameters and yield of green gram. Madras Agri. J., 88(4-6): 360361. 
Muhammad T. I., Fumitake K. and Waichi A. (1994). Growth, canopy structure and seed yield of mungbean as influenced by water stress. J. Fat. Agr., Kyushu Univ., 38: 213-224.

Nair, R. M., Yang, R. Y., Easdown, W. J., Thavarajah, D., Thavarajah, P., Hughes, J. and Keatinge, J. D. (2013). Biofortification of mungbean (Vigna radiata) as a whole food to enhance human health. J. of the Sci. of Food \& Agriculture 93: (8) 1805-1813.

Othmani A., M. Rezgui, S. Cherif, M. Mouelhi and M. Melki. (2015). Effects of water regimes on root and shoot growth parameters and agronomic traits of Tunisian durum wheat (Triticum durum Desf.). Journal of new sciences, Agriculture and Biotechnology, 18(7): 695-702

Patel, A. P., Patel, D. B., Chaudhary, M. M., Parmar P. N. and Patel, H. K. (2016). Influence of Irrigation Scheduling Based on IW: CPE Ratio and Levels of
Sulphur on Growth and Yieldof Rabi Greengram [Vigna radiata (L.) Mills]. Journal of pure and Applied Microbiology, 10 (1): 20-25.

Rajput, M. J., Alam, S. M. and Mangharher, A. M. (1993). Effect of row spacings on the growth and yield of mungbean. Pakistan J. Agric. Res. 14: 2-3.

Rasul, F., Cheema, F. A., Sattar, A., Saleem, M. F. And Washid, M. A. (2012). Evaluting the performance of three mungbean varities grown under varying inter row spacing. J. of Animal and $\mathrm{pl}$. Sci. 22 (4): 1030-1035

Sekhon, H. S., Singh, G. and Brar, J. S. (2002). Effect of population density and planting geometry on the growth and yield of mungbean (Vigna radiate) genotypes. Environ. Ecol., 20: 897-901.

Yadav, N., Sarika, M. A. and Iquebal, A. M. (2009). Silico analysis and homology modeling of coat protein of Mungbean Yellow Mosaic India Virus. J. of Food Legumes 24(2): 138-141.

\section{How to cite this article:}

Karande B. I., H. R. Patel, D. D. Patil, S. B. Yadav and Lunagaria M. M. 2019. Influence of Irrigation Regimes, Row Spacing and Varieties on Biomass Partitioning in Summer Mungbean (Vigna radiata (L)) under Middle Gujarat Agro-Climatic Zone. Int.J.Curr.Microbiol.App.Sci. 8(08): 3083-3090. doi: https://doi.org/10.20546/ijcmas.2019.808.357 